\title{
MOTIF POLIGAMI DENGAN WANITA PEKERJA SEKS KOMERSIAL EKS. LOKALISASI MOROSENENG PERSPEKTIF HUKUM ISLAM
}

\author{
Mega Dwi Aprilia \\ Madrasah Aliyah Sunan Giri Jl. Wonosari Tegal IV no. 3739 \\ Wonokusumo Semampir Surabaya. Email: \\ Megadwiaprilia1004@Gmail.Com

\begin{abstract}
This is a field research that focuses on "Polygamy Motive with Commercial Sex Worker Woman in Moroseneng Localization within the Perspective of Islamic Law'. The research aims to find out how Islamic law views polygamy motive with commercial sex worker women in Moroseneng localization, Benowo, Surabaya. If we compare with the polygamy motive under the time of Prophet Muhammad, the polygamy motive with commercial sex worker women in Moroseneng localization is not much different namely to belp and elevate women to be more noble. It's just all the motives of polygamy by the Prophet Muhammad's time are not entirely implemented. The motive of polygamy with commercial sex worker women in Moroseneng localization is more to meet sexual needs and help. However, helping and raising the degree of commercial sex worker women to be a good woman is the main motive. If the polygamy with commercial sex worker women aimed to help, lead, and guide them in goodness and keep them away from evil, give them a lawful living, and can do justice among the wives, then the legal status of polygamy is recommended (sunnah) and allowed
\end{abstract}

Keywords: Polygamy, commercial sex worker women, localization

\begin{abstract}
Abstrak: Tulisan yang berjudul Motif Poligami dengan Wanita Pekerja Seks Komersial atau Purel Eks. Lokalisasi Moroseneng Perspektif Hukum Islam ini merupakan hasil penelitian lapangan yang bertujuan untuk mengetahui bagaimana hukum Islam memandang motif poligami dengan wanita pekerja seks komersial atau purel eks. Lokalisasi Moroseneng di Daerah Benowo Kota Surabaya. Jika dibandingkan motif poligami Nabi Muhammad Saw., motif poligami wanita pekerja seks di eks. Lokalisasi Moroseneng sebenarnya tidak jauh berbeda, yaitu bertujuan untuk menolong serta mengangkat derajat wanita agar lebih mulia. Hanya saja motif poligami yang dilakukan oleh Nabi Muhammad Saw. tidak diterapkan semuanya. Motif poligami dengan wanita pekerja seks komersial atau purel eks. Lokalisasi Moroseneng adalah motif memenuhi kebutuhan seksual dan menolong. Memenuhi kebutuhan seksual bukan menjadi tujuan utama, menolong serta mengangkat derajat para wanita pekerja seks komersial untuk menjadi wanita baik-baik adalah motif utamanya. Jika poligami dengan wanita Pekerja Seks Komersial bertujuan menolong, memimpin, dan membimbing mereka dalam kebaikan dan
\end{abstract}

AL-HUKAMA

The Indonesian Journal of Islamic Family Law

Volume 07, Nomor 02, Desember 2017; ISSN:2089-7480 
menjaga mereka dari keburukan, memberi mereka nafkah yang halal, serta bisa berbuat adil kepada para istri-istri, maka hukum poligami di sini adalah sunnah dan juga diperbolehkan

Kata Kunci: poligami, Pekerja Seks Komersial, purel, eks. lokalisasi

\section{Pendahuluan}

Perkawinan merupakan suatu akad yang menghalalkan pergaulan antara seorang laki-laki dan perempuan yang bukan mahram serta menimbulkan hak dan kewajiban antara keduanya. Perkawinan merupakan ketentuan yang Allah digariskan untuk manusia agar dapat mengemban tugas memakmurkan bumi. Hal ini ditegaskan oleh Rasulullah saw. dengan pernyataan bahwa perkawinan merupakan sunnah beliau. Yang dimaksud sunnahku (Nabi) ialah tatanan kehidupan yang dilakukan oleh Nabi saw. sebagai ketentuan yang Allah gariskan kepada para nabi sebelumnya dan segenap umat manusia. Dengan kata lain, perkawinan merupakan tabiat (fitrah) yang Allah tanamkan pada diri manusia untuk memelihara kelangsungan hidupnya. Perkawinan merupakan peristiwa yang sakral, dan Islam mengaturnya dengan tata cara yang diatur oleh syariat untuk memuliakan makhluk-Nya sesuai dengan tujuan diciptakannya manusia sebagai makhluk yang paling sempurna di antara makhluk-makhluk yang lainnya, serta mengusahakan agar dalam rumah tangga dapat diciptakan ketenangan berdasarkan cinta dan kasih sayang.1

Salah satu bentuk perkawinan yang sering menjadi bahan kontroversi dalam dalam masyarakat adalah poligami. Dalam Kamus Besar Bahasa Indonesia, poligami adalah sistem perkawinan yang salah satu pihak memiliki atau mengawini beberapa lawan jenisnya dalam waktu yang bersamaan.2 Islam sebagai din (agama, jalan hidup) yang sempurna telah memberikan sedemikian lengkap hukumhukum untuk memecahkan problematika kehidupan umat manusia. Islam telah membolehkan kepada seorang lelaki untuk beristri lebih dari satu orang. Hanya saja, Islam membatasi jumlahnya, yakni

1Muhammad Daud Ali, Hukum Islam dan Peradilan Agama (Jakarta: PT Raja Grafindo Persada,1997), 27.

2Departemen P dan K, Kamus Besar Bahasa Indonesia (Jakarta: Balai Pustaka, 1989). 
maksimal empat orang istri, dan mengharamkan lebih dari itu. Hal ini didasarkan firman Allah Swt. yang artinya:

Dan jika kamu khawatir tidak akan mampu berlaku adil terbadap (bak-bak) perempuan yatim (bilamana kamu menikabinya), maka nikailah perempuan (lain) yang kamu senangi, dua, tiga, atau empat. Tetapi jika kamu khawatir tidak akan mampu berlaku adil, maka (nikailah) seorang saja, atau hamba sahaya perempuan yang kamu miliki, yang demikian itu lebih dekat agar kamu tidak berbuat zalim. (QS an-Nisa' [4]: 3).3

Berbicara poligami, tidak bisa lepas dari apa yang dilakukan oleh Rasulullah Saw. Beliau berpoligami untuk memberikan contoh pengaplikasian ayat-ayat yang membolehkan beristri lebih dari satu. Adapun makna yang terkandung dibalik praktek poligami Rasulullah sebagai berikut:4

1. Rasulullah diutus untuk melindungi dan mengangkat martabat kaum wanita, anak-anak yatim, para budak, dan kaum tertindas lainnya.

2. Rasulullah menyuruh umatnya untuk berumah tangga bukan hanya untuk menyalurkan fitrah seksnya, melainkan juga untuk membentuk keluarga yang sejahtera, bahagia, dan menumbuhkan generasi Islami yang kuat di masa depan.

Pada zaman sekarang, poligami dilaksanakan dengan berbagai motif yang antara lain adalah untuk memperoleh keturunan, mencukupi kebutuhan ekonomi, bahkan hanya sebagai wadah penyalur kepuasan seksual. Oleh karena bergesernya motif mulia poligami yang dicontohkan oleh Rasulullah saw. tersebut, maka poligami lebih sering dipandang sebagai penyebab rusaknya rumah tangga seseorang dan pemuas nafsu belaka, sehingga banyak orang yang menentang adanya praktik poligami, terutama kalangan perempuan.

Dalam masyarakat, praktik poligami terjadi dalam berbagai kalangan. Dari kalangan atas sampai kalangan bawah, dari kalangan agamis sampai kalangan abangan sekalipun, bahkan yang lebih

3Departemen Agama, Al-Qur'an dan Terjemahannya (Jakarta: Pustaka Amani, 2002), 99.

4Agus Mustofa, Poligami Yunk!? (Surabaya: PADMA Press, 2010), 225. 
menarik poligami dilakukan juga oleh sebagian laki-laki dengan wanita pekerja seks komersial atau purel, yang umumnya dipandang oleh masyarakat sebagai wanita yang hina dan kotor. Adapun praktik poligami seperti ini dapat ditemukan di wilayah eks. Lokalisasi Moroseneng di Daerah Benowo Kota Surabaya Moroseneng. Keberadaan lokalisasi tersebut dijadikan oleh sebagian masyarakat untuk mengais rizeki, sehingga keberadaannya sempat dipertahankan, meskipun pada akhirnya ditutup juga.

Terdapat beberapa wanita pekerja seks komersial atau purel eks. Lokalisasi Moroseneng yang dinikahi oleh laki-laki yang telah memiliki istri. Hal ini tentunya menimbulkan pertanyaan besar, mengapa para laki-laki yang sudah memiliki istri tersebut bersedia melakukan poligami dengan seorang wanita pekerja seks komersial atau purel yang bahkan dianggap buruk, padahal masih banyak perempuan baik-baik yang lebih pantas untuk dijadikan berpoligami lebih daripada wanita pekerja seks komersial atau purel. Lantas motif apakah yang melatarbelakangi terjadinya praktik poligami dengan wanita Pekerja Seks Komersial atau purel eks. Lokalisasi Moroseneng di daerah Benowo Kota Surabaya tersebut beserta hukumnya, dalam arti sesuai atau tidaknya dengan motif poligami yang diajarkan oleh Rasulullah saw. akan dibahas lebih mendalam dalam tulisan ini.

\section{Poligami Menurut Hukum Islam}

Kata Poligami berasal dari bahasa Yunani, yaitu dari kata Poli atau Polus yang artinya banyak, dan kata gamain atau gamus yang berarti kawin atau perkawinan, maka ketika kedua kata ini digabungkan akan berarti suatu perkawinan yang banyak dan bisa jadi dalam jumlah yang tidak terbatas. Akan tetapi, dalam Islam poligami mempunyai arti perkawinan yang lebih dari satu dengan batasan umumnya dibolehkan sampai empat wanita.5 Menurut $\mathrm{Ny}$. Soemiyati, poligami diartikan sebagai perkawinan antara seorang laki-laki dengan wanita lebih dari seorang dalam jangka waktu yang sama.6 Adapun dalam pengertian umum yang berlaku di masyarakat,

5Khairuddin Nasution, Riba dan Poligami: Sebuah Studi atas Pemikiran Muh. Abduh (Yogyakarta: Academia, t.t.), 84.

6Sumiati, Hukum Perkawinan Islam dan Undang-Undang Perkawinan No.1 Tabun 1974 (Yogyakarta: Liberti, 1985), 47. 
perkawinan poligami itu diartikan dengan perkawinan seorang lakilaki dengan banyak wanita.

Poligami memiliki akar sejarah yang cukup panjang sepanjang sejarah peradaban manusia itu sendiri. Sebelum Islam datang ke jazirah Arab, poligami merupakan sesuatu yang telah mentradisi bagi masyarakat arab. Poligami pada masa itu dapat disebut dengan poligami tidak terbatas. Lebih dari itu tidak ada gagasan keadilan di antara para istri, suamilah yang menentukan siapa yang paling ia sukai dan siapa yang ia pilih untuk dimiliki secara tidak terbatas. Para istri harus menerima takdir mereka tanpa ada usaha untuk memperoleh keadilan sama sekali.7

Kebanyakan umat dahulu dan agama sebelum Islam membolehkan kawin tanpa batas yang kadang-kadang sampai sepuluh orang wanita, bahkan ada yang sampai ratusan tanpa suatu syarat dan ikatan. Akan tetapi, setelah Islam datang perkawinan lebih dari seorang ini dibatasi dan bersyarat.8 Kedatangan Islam dengan ayat-ayat poligaminya kendatipun tidak menghapus praktik ini, namun Islam membatasi kebolehan poligami hanya sampai empat orang istri dengan syarat-syarat yang ketat pula, seperti:

1. Keharusan berlaku adil di antara para istri.

2. Mampu menjaga istri-istrinya

3. Mampu memberi nafkah

Sebagaimana hukum menikah, hukum poligami juga tergantung kondisi seorang laki-laki, kebutuhannya terhadap poligami, dan kemampuannya memenuhi hak-hak istrinya. Pada dasarnya, poligami itu hukumnya mubah (boleh) seperti yang diisyarahkan oleh firman Allah yang artinya sebagai berikut:

Dan jika kamu khawatir tidak akan mampu berlaku adil terbadap (bak-hake) perempuan yatim (bilamana kamu menikabinya), maka nikailah perempuan (lain) yang kamu senangi, dua, tiga, atau empat. Tetapi jika kamu khawatir tidak akan mampu berlaku adil, maka (nikailab) seorang saja, atau bamba sahaya perempuan yang kamu

7Asghar Ali, Pembebasan Perempuan (Yogyakarta: Lkis, 2003), 111.

8 Syekh Muhammad Yusuf Qardhawi, Halal \& Haram Dalam Islam, terj. Hamidy Muammal (Surabaya: PT Bina Ilmu Surabaya, 2010), 263. 
miliki, yang demikian itu lebih dekat agar kamu tidak berbuat zalim. (QS. an-Nisa': 3).9

Selanjutnya pada surat an-Nisa' ayat 129, Allah juga berfirman yang artinya:

Dan kamu sekali-kali tidak akan dapat Berlaku adil di antara isteriisteri(mu), walaupun kamu sangat ingin berbuat demikian, karena itu janganlab kamu terlalu cenderung (kepada yang kamu cintai), sebingga kamu biarkan yang lain terkatung-katung. dan jika kamu Mengadakan perbaikan dan memelihara diri (dari kecurangan), Maka Sesunggubnya Allah Maha Pengampun lagi Maha Penyayang.

Kedua ayat di atas menjelaskan kehalalan poligami dengan syarat dapat berlaku adil. Jika syarat ini tidak dapat dipenuhi, di mana seseorang suami yakin bahwa ia akan terjatuh kepada kezaliman dan menyakiti istri-istrinya serta tidak dapat memenuhi hak-hak mereka dengan adil, maka poligami menjadi haram. Jika ia merasa kemungkinan besar menzalimi salah satu istrinya, maka poligami menjadi makruh. Akan tetapi, jika ia yakin akan terjatuh pada perbuatan zina jika tidak berpoligami, maka poligami menjadi wajib atasnya. Adapun dasar Hukum Hadisnya adalah:

Dari Qais bin Harits, ia berkata: aku masuk. Islam sedang aku memiliki delapan istri, lalu aku menghadap Nabi Saw kemudian kuterangkan kepadanya hal itu, lalu ia bersabda, "Piliblah empat diantara mereka". (HR Abu Daud dan Ibnu Majab) 10

Para Fuqaha berbeda pendapat mengenai ketentuan poligami, meskipun dasar pijakan mereka adalah sama, yakni mereka mendasarkan pada satu ayat dalam al-Qur'an, yaitu QS. an-Nisa': 3 seperti di atas. Menurut jumhur ulama ayat di atas turun setelah Perang Uhud selesai, ketika banyak pejuang Muslim yang gugur menjadi syuhada'. Sebagai konsekuensinya banyak anak yatim dan janda yang ditinggal mati ayah atau suaminya. Hal ini juga berakibat terabaikannya kehidupan mereka terutama dalam hal pendidikan dan

9Departemen Agama, Al-Qur'an dan Terjemahannya, 99.

10 Mu'ammal Hamidy, et. al. Terjemahan Nailul Authar, jilid 5 (Surabaya: Pt Bina Ilmu, 1993), 2201. 
Mega Dwi Aprilia: Motif Poligami...

masa depan mereka. Kondisi inilah yang melatarbelakangi disyariatkannya poligami dalam Islam.11

Ibnu Jarir al-Thabari sangat setuju dengan pendapat yang mengatakan bahwa makna ayat di atas merupakan kekhawatiran tidak mampunyai seorang wali yang dapat berbuat adil terhadap harta anak yatim. Oleh karena itu, jika sudah khawatir kepada anak yatim, mestinya juga khawatir terhadap perempuan. Akan tetapi, janganlah menikahi mereka kecuali dengan perempuan yang kalian yakin bisa berbuat adil, satu hingga empat orang. Sebaliknya, jika ada kekhawatiran tidak sanggup berbuat adil ketika berpoligami, maka cukup menikahi seorang isteri saja.12

Al-Qurthubi sepakat dengan al-Zamakhsyari dalam hal menikahi budak yang akan digauli oleh tuannya. Namun al-Qurthubi berbeda dengan al-Zamakhsyari dalam memahami jumlah maksimal perempuan yang dijadikan istri dalam berpoligami. Al-Qurthubi sepakat dengan apa yang ditegaskan oleh Nabi saw. ketika menyuruh sahabat untuk menyisakan istrinya maksimal empat orang. Dengan demikian, menurut al-Qurthubi jumlah maksimal istri bagi suami yang berpoligami adalah empat orang. 13

Al-Syaukani menyebutkan, bahwa sebab turunnya QS. anNisa': 3 berhubungan dengan kebiasaan orang-orang Arab praIslam. Di antara kebiasaan mereka adalah para wali yang ingin menikahi anak yatim dengan tidak memberikan mahar yang jumlahnya sama dengan mahar yang diberikan kepada perempuan lain. Oleh karena itu, kalau tidak bisa memberikan mahar yang sama antara perempuan yang yatim dan non-yatim, Allah menyuruh untuk menikahi perempuan yang non-yatim saja, maksimal empat orang dengan syarat dapat berbuat adil. Jika tidak dapat berbuat adil, maka cukup satu saja. al-Syaukani juga menegaskan bahwa menikahi wanita lebih dari empat orang hukumnya haram karena bertentangan

11Khairuddin, Nasution, Riba \& Poligami: Sebuah Studi atas Pemikiran Mubammad Abduh, cet. I (Yogyakarta: Pustaka Pelajar, 1996), 85.

12Ibnu Jarir Al-Thabari, Jami' al-Bayan fi Tafsir al-Qur'an, jilid IV (Beirut: Dar alFikr, 1978), 155.

13Al-Qurthubi, Al-Jami' li al-Abkam al-Qur'an, jilid V (Kairo: Dar al-Kitab al'Arabiyyah, 1967), 17. 
dengan sunnah Nabi dan bertentangan dengan pemahaman bahasa Arab yang umum.14

Sebagaimana umumnya para ahli tafsir, dalam menafsirkan QS. an-Nisa': 129, al-Syaukani menegaskan bahwa bagaimanapun usaha untuk berbuat adil, manusia tidak akan mampu, lebih-lebih kalau dihubungkan dengan kemampuan membagi di bidang nonmateri. Oleh karena itu, Allah melarang untuk condong kepada salah satu yang mengakibatkan yang lain menjadi terlantar. Dengan kata lain, harus ada upaya maksimal dari seorang suami untuk dapat berbuat adil kepada para istrinya ketika berpoligami.15 Muhammad Rasyid Ridha sependapat dengan gurunya, Muhammad Abduh, mengenai haramnya berpoligami, jika suami tidak mampu berbuat adil kepada istri-istrinya. 16

Imam syafi'i menegaskan pada kasus poligami ini beliau mencoba mentranformasikan hadis dalam praktik Nabi Muhammad saw. terhadap wahyu yang diturunkan. Kemudian pada kasus poligami ini, nabi sedang mengejawantahkan QS. an-Nisa': 2-3 mengenai perlindungan terhadap janda mati dan anak-anak yatim. Poligami Nabi merupakan media untuk menyelesaikan problem sosial bisa dilihat pada teks-teks hadis yang membicarakan perkawinan-perkawinan nabi.17

Sayyid sabiq memaparkan Imam Syafi'i berkata bahwa masalah poligami telah ditunjukkan oleh sunnah Rasulullah sebagai penjelasan dari firman Allah, bahwa selain Rasulullah tidak ada seorangpun yang dibenarkan lebih dari empat perempuan. Penganut madzab Syafi'i mensyaratkan mampu memberi nafkah bagi orang yang akan berpoligami. Dalam pemahaman madzab Syafi'i, jaminan yang mansyaratkan kemampuan memberi nafkah sebagai syarat poligami adalah syarat agama, maksudnya bahwa jika yang

14Al-Syaukani, Fath al-Qadir: al-Jami' Bain Fann al-Riwayah wa al-Dirayah min 'Ilm alTafsir, jilid I (Beirut: Dar al-Fikr, 1973), 420.

15Ibid., 521.

16Khairuddin Nasution, Riba \& Poligami: Sebuab Studi atas Pemikiran Mubammad Abduh, 104.

17Sayid Sabiq, Fikih Sunnah, terj. Moh Tholib, juz VI (Bandung: PT. Alma'arif,1990), 149. 
Mega Dwi Aprilia: Motif Poligami...

bersangkutan tahu bahwa dia tidak mampu memberi nafkah bukan syarat putusan hukum.18

Adapun beberapa motif yang membolehkan poligami, menurut al-Maraghi, adalah 1) karena isteri mandul sementara keduanya atau salah satunya sangat mengharapkan keturunan; 2) apabila suami memiliki kemampuan seks yang tinggi sementara isteri tidak mampu meladeni sesuai dengan kebutuhannya 3) jika suami memiliki harta yang banyak untuk membiayai segala kepentingan keluarga, mulai dari kepentingan isteri sampai kepentingan anakanak 4) jika jumlah perempuan melebihi jumlah laki-laki yang bisa jadi dikarenakan perang. Al-Maraghi juga menegaskan hikmah pernikahan poligami yang dilakukan Nabi yang menurutnya ditujukan untuk syiar Islam. Sebab jika tujuannya untuk pemuasan nafsu seksual, tentu Nabi akan memilih perempuan-perempuan cantik dan yang masih gadis. Sejarah membuktikan bahwa yang dinikahi Nabi semuanya janda kecuali 'Aisyah. Terkait dengan QS. an-Nisa': 129 al-Maraghi mencatat, yang terpenting harus ada upaya maksimal untuk berbuat adil, sedangkan di luar kemampuan manusia, bukanlah suatu yang harus dilakukan.19

Di Indonesia, masalah poligami diatur dalam UU No. 1 Tahun 1974 Tentang Perkawinan. Kendatipun Undang-undang Perkawinan ini menganut asas monogami seperti yang terdapat dalam pasal 3 yang menyatakan bahwa, "Pada azasnya dalam suatu perkawinan seorang pria hanya boleh mempunyai seorang istri dan seorang wanita hanya boleh mempunyai seorang suami." Akan tetapi, pada bagian yang lain dinyatakan dalam keadaan tertentu poligami dibenarkan, tepatnya dalam pasal 4 ayat 2 Undang-undang Perkawinan dinyatakan bahwa seorang suami hanya diberikan izin oleh Pengadilan untuk beristri lebih dari seorang apabila:

1. Istri tidak dapat menjalankan kewajibannya sebagai istri

2. Istri mendapat cacat badan atau penyakit yang tidak dapat disembuhkan

18Imam Taqiyuddin Abi Bakr al-Husaini, Kifayah Al-Akhyar, jilid II (Bandung: PT. Al-Ma'arif, t.t.), 38.

19Ahmad Musthafa Al-Maraghi, Tafsir al-Maraghi, jilid IV (Mesir: Mushthafa alBab al-Halabi, 1969), 173. 
3. Istri tidak dapat melahirkan keturunan.20

Dengan adanya pasal-pasal yang membolehkan untuk berpoligami kendatipun dengan alasan-alasan tertentu, jelaslah bahwa asas yang dianut oleh Undang-undnag Perkawinan sebenarnya bukan asas monogami mutlak melainkan disebut monogami terbuka atau meminjam bahasa Yahya Harahap, poligami ditempatkan pada status hukum yang darurat (emergency law) atau dalam keadaan yang luar biasa (extra ordinary circumstanse). Di samping itu, lembaga poligami tidak semata-mata menjadi kewenangan penuh suami tetapi atas dasar izin dari hakim (pengadilan).21

Adapun dalam pasal 5 ayat 1 Undang-undang Perkawinan tersebut, syarat-syarat yang harus dipenuhi bagi seorang suami yang ingin melakukan poligami ialah:

1. Adanya persetujuan dari istri/ istri-istrinya.

2. Adanya kepastian bahwa suami mampu menjamin hidup istri-istri dan anak-anak mereka.

3. Adanya jaminan bahwa suami akan berlaku adil terhadap istri dan anak mereka. 22

Selain dibahas dalam UU No. 1 Tahun 1974 sebagaimana telah dijelaskan di atas, persoalan poligami ini dipaparkan juga dalam Kompilasi Hukum Islam (KHI), yang merupakan produk fikih Indonesia, pada bagian IX dengan judul "Beristri lebih dari satu orang" yang diungkap dari pasal 55 sampai 59.

Pasal 55 KHI menyatakan:

(1)Beristri lebih dari satu orang pada waktu bersamaan hanya sampai empat orang istri

(2)Syarat utama beristri lebih dari satu orang, suami harus mampu berlaku adil terhadap istri-istri dan anak-anaknya.

(3)Apabila syarat utama yang disebut pada ayat (2) tidak mungkin dipenuhi, suami dilarang beristri lebih dari satu orang.

Pasal 56 KHI menyatakan:

20 Pasal 3 dan 4 UU No. 1 Tahun 1974 Tentang Perkawinan.

21 Yahya Harahap, Hukum Perkawinan Nasional (Medan: Zahir Tranding Co Medan, 1975), 25-26.

22 Pasal 5 ayat 1 UU No. 1 Tahun 1974 Tentang Perkawinan. 
(1)Suami hendak beristri lebih dari satu orang harus mendapat izin dari Pengadilan Agama.

(2)Pengajuan permohonan izin dimaksudkan pada ayat 1 dilakukan menurut tata cara sebagaimana diatur dalam Bab VIII PP No. 9 Tahun 1975.

(3)Perkawinan yang dilakukan dengan istri kedua, ketiga atau keempat tanpa izin dari Pengadilan Agama, tidak mempunyai kekuatan hukum.

Pasal 57 KHI menyatakan:

Pengadilan Agama hanya memberi izin kepada suami yang akan beristri lebih dari seorang apabila:

a. istri tidak dapat menjalankan kewajiban sebagai istri.

b. istri mendapat cacat badan atau penyakit yang tidak dapat disembuhkan.

c. istri tidak dapat melahirkan keturunan.

Pasal 57 KHI menyatakan:

(1) Selain syarat utama yang disebut pada pasal 55 ayat (2) maka untuk memperoleh izin pengadilan Agama harus pula dipenuhi syarat-syarat yang ditentukan pada pasal 5 Undang-undang No. 1 Tahun 1974 yaitu:

a. adanya persetujuan istri;

b. adanya kepastian bahwa suami mampu menjamin keperluan hidup istri-istri dan anak-anak mereka.

Selanjutnya pada pasal 59 juga digambarkan betapa besarnya wewenang Pengadilan Agama dalam memberikan izin, sehingga bagi istri yang tidak mau memberikan persetujuan kepada suaminya untuk berpoligami, persetujuan itu dapat diambil alih oleh Pengadilan Agama.23

Berbicara poligami, tentulah tidak dapat lepas dari praktik poligami yang dilakukan oleh Nabi saw. yang mana beliau berpoligami untuk memberikan contoh aplikasi ayat-ayat yang bercerita tentang beristri lebih dari satu. Poligami memang diperbolehkan, akan tetapi banyak di antara kita yang kurang jernih

23 Pasal 55-59 Kompilasi Hukum Islam. 
dalam memahami makna poligami itu sendiri, sehingga maksud yang semula mulia menjadi pengertian yang hanya untuk memuaskan hasrat seksual belaka.24 Adapun makna mulia yang terkandung di balik praktek poligami Nabi Muhammad saw. adalah:

1. Nabi saw. diutus oleh Allah untuk menebarkan kasih sayang kepada seluruh alam.

2. Nabi saw. diutus oleh Allah untuk memberi contoh dan keteladanan akhlak yang mulia kepada seluruh umat manusia.

3. Nabi saw. diutus oleh Allah untuk melindungi dan mengangkat martabat kaum wanita, anak-anak yatim, para budak dan kaum yang tertindas lainnya

Berbagai ayat yang diwahyukan kepada Nabi perlu dicontohkan dan diteladankan secara nyata, agar menjadi jelas maknanya. Dengan demikian, motif atau alasan di balik praktik poligami Nabi itu sebenarnya adalah manifestasi aturan Allah di dalam al-Qur'an.25 Berikut istri-istri Nabi beserta motif atau alasan poligami beliau:

\section{Khadijah binti Khuwaili}

Sebelum menjadi rasul tepatnya saat berusia 25 tahun, Nabi Muhammad Saw. menikahi Siti Khadijah yang sudah janda berusia 40 tahun. Dengan istri pertamanya ini Rasulullah mempunyai 6 orang anak, yang terdiri dari 2 laki-laki, Qasim dan Abdullah yang keduanya meninggal ketika masih kecil dan 4 perempuan yang bernama Zainab, Ruqaiyyah, Ummu Kulthum dan Fatimah. Siti Khadijah meninggal pada usia 68 tahun setelah berumah tangga dengan Nabi selama 28 tahun. Adapun Rasulullah menikah dengan Khadijah karena kebaikan dan kemuliaan akhlaknya, bukan karena kecantikannya. Selama berumah tangga dengan Khadijah itu, Rasulullah tidak pernah berpoligami, meskipun bisa dan sangat memenuhi syarat untuk itu.

\section{Saudah binti Zam'ah}

Saudah binti Zam'ah dinikahi Rasulullah setelah khadijah wafat dan juga setelah ditinggal mati suaminya, Sakran ibn Amr.

24Agus Mustofa, Benarkah al-Qur'an Menyuruh Berpoligami karena Alasan Syabwat? (Surabaya: Padma Press, 2008), 225.

25Ibid.,227. 
Mega Dwi Aprilia: Motif Poligami...

Sakran dan Saudah merupakan sahabat rasul yang ikut hijrah ke Madinah. Beliau kasihan karena Saudah hidup sebatangkara serta dikucilkan keluarganya yang kafir, akibat ia masuk Islam.

3. Aishab binti Abu Bakr

Aishah binti Abu Bakr adalah anak sahabat Rasul, Abu Bakar. Dialah sahabat Rasulullah yang paling terpercaya dan sangat berjasa sejak awal perjuangan Islam. Mereka bersamasama melewati saat-saat yang sangat kritis dan berbahaya. Abu Bakar juga merupakan khalifah pertama sesudah Nabi wafat. Oleh sebab itu, salah satu motif perkawinan Rasulullah dengan Aishah adalah mengikat persaudaraan yang lebih erat dengan Abu Bakar, agar lebih kukuh dalam perjuangannya.

4. Hafshah binti Umar bin Khattab

Sama dengan Aishah, Hafshah adalah anak sahabat dekat Rasul, yaitu Umar. Dialah Khalifah ke dua yang menggantikan Abu Bakar. Rasul mengikat kekeluargaan lebih erat dengan Umar dengan cara menikahi anaknya.

5. Zainab binti Khuzaimah

Zainab binti Khuzaimah adalah janda beberapa kali sebelum menikah dengan Rasulullah. Suaminya yang terakhir adalah Ubaidah Ibn Harith yang gugur di perang Badar membela Islam. Rasulullah merasa kasihan kepadanya dan menjadikannya sebagai istri. Zainab dikenal sebagai wanita yang sangat welas asih kepada orang-orang miskin, sehingga Rasulullah sangat menghargai kemuliaan hatinya itu. Akan tetapi, setelah delapan bulan setelah dinikahi, Zainab meninggal dunia.

6. Hindun binti Umayah

Hindun binti Umayah dikenal juga sebagai Ummu Salamah. Suami sebelumnya adalah Abu Salamah. Wanita ini dinikahi Rasulullah setelah ditinggal mati suaminya, yang gugur di medan perang Uhud. Dia memiliki empat orang anak, yaitu Zainab, Salam, Umar dan Durrah. Hindun dikenal sebagai pejuang wanita di medan perang Uhud.

7. Juwairiyah binti Harith

Juwairiyah binti Harith adalah tawanan perang yang berasal dari bani Musthaliq. Pada jaman itu seorang tawanan perang tidak memiliki harga di hadapan tentara yang menawannya. Oleh 
karena itu, Rasulullah memberikan pelajaran kepada tentara Islam untuk menghargai mereka yang menjadi tawanan perangnya, terutama para wanita. Rasulullah meminangnya menjadi istri yang dihormati oleh kaum muslimin.

8. Zainab binti Jahshi

Zainab binti Jahshi adalah sepupu Rasulullah yang dinikahkan oleh Rasulullah dengan anak angkatnya yang bernama Zaid ibn Harith yang semula adalah budak. Akan tetapi, tidak ada kecocokan setelah mereka menikah, sehingga Zainab diceraikan oleh Zaid. Rasulullah merasa kasihan kepada Zainab dan kemudian menikahinya. Pernikahan ini sekaligus menjadi penerapan hukum, bahwa menikahi bekas istri anak angkat diperbolehkan dalam Islam.

9. Raihanah binti Zaid

Raihanah binti Zaid merupakan seorang budak Rasulullah yang berasal dari bani Quraizah. Ada juga yang mengatakan diperoleh dari tawanan perang. Rasul memerdekakan dan menikahinya. Dikabarkan pernah dicerai, tetapi kemudian dirujuk kembali. Motifnya tidak lain adalah mengangkat martabat seorang budak dan menghapus perbudakan serta mengangkat derajat wanita agar lebih mulia.

\section{Ramlab binti Abu Sufyan}

Sebelumnya Ramlah binti Abu Sufyan dinikahi oleh Ubaidillah bin Jabsy dan hijrah bersamanya ke Habsyah. Suaminya tersebut murtad dan menjadi Nashrani serta meninggal di sana. Akan tetapi, Ummu Habibbah tetap istiqomah terhadap agamanya. Ketika Rasulullah saw. mengirim Amr bin Umayyah Adb-Dhomari untuk menyampaikan surat kepada raja Najasy pada bulan Muharram tahun 7 Hijrah, Rasulullah mengkhitbah Ummu Habibah melalui raja tersebut dan dinikahi serta dipulangkan kembali ke Madinah bersama Surabbil bin Hasanah dengan alasan untuk menghiburnya dan memberikan sosok pengganti yang lebih baik baginya serta penghargaan kepada mereka yang hijrah ke Habasyah, karena sebelumnya telah mengalami siksaan dan tekanan yang berat di Mekkah

11.Shafiyah binti Huyay 
Mega Dwi Aprilia: Motif Poligami...

Shafiyah binti Huyay berasal dari Bani Israel dan merupakan tawanan perang Khaibar. Rasulullah saw. memilihnya untuk dimerdekakan serta dinikahinya setelah menaklukan Khaibar pada tahun 7 Hijriyyah. Pernikahan tersebut tidak lain bertujuan untuk menjaga kedudukannya sebagai anak dari pemuka kabilah.

\section{Maimunah binti Harith.}

Maimunah binti Harith adalah seorang janda yang sudah berusia lanjut dan merupakan saudara dari Ummu Al-Fadhl Lubabah binti Al-Harith yang dinikahi Rasulullah di bulan Dzulqa'dah tahun 7 Hijrah pada saat melaksanakan Umrah Qadho.26

Selain motif-motif Nabi dalam melakukan poligami, ada beberapa motif yang lain yaitu sebagai berikut:

1. Kelebihan jumlah perempuan daripada laki-laki.

2. Istri mempunyai penyakit.

3. Suami mempunyai nafsu yang tinggi sehingga tidak puas dengan satu istri.

4. Menghindari selingkuh dan zina.27

\section{Motif Poligami dengan Wanita Pekerja Seks Komersial Eks. Lokalisasi Moroseneng di Daerah Benowo Kota Surabaya}

Moroseneng adalah salah satu lokalisasi di Surabaya yang berdiri sejak 1970. Istilah Moroseneng berasal dari dua kata, yaitu moro dan seneng. Moro yang berarti datang dan seneng yang berarti senang. Jadi pengertian moroseneng adalah anda datang maka akan senang. Sebelum adanya lokalisasi Moroseneng, Klakah Rejo merupakan daerah yang paling sepi dan angker, masih banyak kavlingan-kavlingan kosong dan belum sepadat sekarang yang sudah diisi dengan bangunan rumah yang sudah padat merayap, 28 sehingga dulu sekitar pukul 18.00 WIB daerah ini selalu sepi.

Sebelum adanya lokalisasi Moroseneng, perekonomian mayoritas masyarakat Kalakah Rejo tergolong minim, sehingga salah

26Aishah Bintush-Shati', Istri-istri Nabi, Fenomena Poligami di Mata Seorang Tokoh Wanita (Bandung: Pustaka Hidayah, 2001), 35.

27Mulia Musdah Siti, Islam Menggugat Poligami (Jakarta: PT Gramedia Pustaka Utama, 2007), 61.

28Sunarto, Wawancara Terbuka, Surabaya, 06 Desember 2016. 
satu orang yang berani membuka tempat pelacuran di situ.29 Tidak disangka, ternyata tempat pelacuran tersebut berkembang pesat dan bisa mengubah suasana Kalakah Rejo yang dulunya sepi menjadi serba kecukupan, bahkan lokalisasi tersebut menjadi tempat sebagian masyarakat menggantungkan kehidupannya, sehingga keberadaannya sempat dipertahankan meskipun terdapat berbagai pro kontra dalam masyarakat. Adapun kawasan Moroseneng ini berbaur dengan pemukiman penduduk yang padat di kawasan Klakah Rejo Surabaya. Terdengar suara mesin kendaraan dan suarasuara musik di berbagai wisma yang ada disana.

Di daerah tersebut ada tiga pelaku poligami (suami) dan wanita Pekerja Seks Komersial atau purel (istri) yang dijadikan objek penelitian dengan identitas sebagai berikut:

1. Subjek pertama (Pelaku poligami (Suami) bernama Sy, umur: 47 Tahun, pekerjaan: swasta, agama: Islam menikah dengan wanita pekerja seks komersial (Istri) bernama Sr, umur: 38 Tahun, pekerjaan: wanita PSK, agama : Islam)

2. Subjek kedua (Pelaku Poligami (Suami) bernama: Sn, umur: 47 Tahun, pekerjaan: Swasta, agama: Islam menikah dengan wanita pekerja seks komersial (Istri) bernama Si, umur: 51 Tahun, pekerjaan: Wiraswasta, agama: Islam)

3. Subjek ketiga (Pelaku Poligami (Suami) yang bernama Wn menikah dengan wanita pekerja seks komersial (Istri) yang bernama Rh)

Banyak hal yang menjadikan motif poligami dengan wanita pekerja seks komersial eks. Lokalisasi Moroseneng yang didapatkan dari ketiga pelaku di atas. Berikut cuplikan wawancaranya:

1. Subjek pertama dari pasangan suami istri yang berinisial Sy dengan $\mathrm{Sr}$

\section{a. Pernyataan Suami}

"Awalnya saya bertemu dengan istri saya di tempat karaoke, dikenalkan sama teman saya, saya sudah mengetahui kalau istri saya ini wanita PSK atau purel, setelah acara karaokean itu saya masih sering bertemu dengan dia di lokalisasi Moroseneng, dia juga menemani saya minum (minuman

29Riyanto, Wawancara Terbuka, Surabaya, 06 Desember 2016. 
beralkohol) menemani karaokean, dan juga menemani saya tidur. Namanya juga laki-laki yang dibutuhkan hanya nafsu dan kenikamatan. Kemudian saya mempunyai niatan menikahi dia tapi saat itu saya sudah mempunyai istri dan anak satu. Kalau ditanyai motif kenapa melakukan poligami dengan wanita PSK tidak ada melainkan nafsu. Kemudian tak nikahi secara siri. Istri saya tidak mengetahui kalau saya menikah lagi, kalaupun saya mau pulang kesini saya bilang kerja ke istri saya. Setelah menikah kehidupan saya dengan istri ya begini saja, saya tidak melarang kalau istri saya masih kembali ke pekerjaannya sebagai PSK atau purel dan saya juga jarang pulang kesini, hanya saja kalau masalah adil saya tetap berlaku adil dengan memberikan nafkah.” 30

b. Istri (wanita Pekerja Seks Komersial)

"Awalnya dulu saya di Surabaya diajak oleh teman saya, saya juga sudah tau kalau saya akan diajak kerja sebagai PSK atau purel, ekonomi yang membuat saya mau bekerja sebagai PSK atau purel. Kemudian saya bertemu suami, saya diajak menikah tapi dijadikan istri kedua, saya menerima asalkan dia bisa memberi saya uang secara rutin, tetapi saya masih bekerja sebagai wanita PSK atau purel kalau suami lagi pulang ke rumah istri pertama, saya fikir-fikir masih kurang uang yang diberikan oleh suami saya buat kehidupan sekalian buat hiburan jika tidak ada teman. Saya tidak ingin dinikahi sah ya begini saja, suami saya juga mempunyai istri dan anak juga, saya tidak menuntut untuk dinikahi sah, mengikuti hidup saja. Selama 2 tahun ini saya dinikahi sirri oleh suami, dia tidak bisa adil dalam hal nafkah. Mangkanya saya masih bekerja sebagai PSK di Moroseneng, gimana lagi suami saya saja jarang pulang, jarang menafkahi saya, itu juga sebagai alasan saya mengapa tidak mau dinikah sah sama dia." ${ }_{31}$

2. Subjek kedua dari pasangan suami istri yang berinisial Sn dengan $\mathrm{Si}$

30Sy, Wawancara Terbuka, Surabaya, 09 Desember 2016.

31Sr, Wawancara Terbuka, Surabaya, 09 Desember 2016. 
a. Pernyataan Suami

"Awalnya dulu bertemu sama istri saya di warung belakang (warung Moroseneng), tau sendiri kan kalau istri saya menjadi PSK atau purel di Mororseneng, saat itu posisi saya sudah mempunyai istri dan anak-anak saya dari istri pertama juga sudah pada besar, awalnya dulu hanya kenalan saja buat hiburan. Tapi saat istri saya mengetahui bahwasanya saya mempunyai kenalan di Moroseneng istri saya tidak marah melainkan mengajak dia ke rumah bertemu dengan istri pertama saya, tanpa diduga ternyata istri pertama saya menyuruh saya untuk menikahi dia, padahal istri pertama saya sudah mengetahui kalau istri kedua saya adalah PSK di Moroseneng. Tapi saat saya bertanya kenapa dek kamu menyuruhku menikahi dia? Apa ikhlas kalau kamus saya poligami?' istri saya menjawab 'tidak papa mas pokoknya dia bisa menjaga kamu dengan anak-anak, bisa menolong dia jadi orang baik, saya juga begini keadaannya sudah tidak bisa berbuat apa-apa'. Ya begitu setelah mendapatkan izin, saya menikahi istri yang kedua meskipun masih pernikahan sirri. Kalau ditanya motif nya ya menerima keinginan dari istri saya yang pertama untuk saya menikah lagi biar saya bisa menolong istri saya yang kedua untuk jadi orang baik-baik dan tidak kembali ke pekerjaannya menjadi PSK atau purel. Awalnya juga saya tidak pernah melakukan hal-hal buruk sama dia, hanya saja kenal langsung saya ajak menikah, niat saya juga baik niat lillahita'ala. Istri saya yang pertama mengetahui dan mengikhlaskan, tapi sekarang istri pertama saya sudah tidak ada, dia sudah meninggal, maka dari itu istri saya yang kedua ini akan saya nikahi secara sah. Alhmdulillah setelah menikah, dia menjadi wanita yang baik, mengikuti pengajian serta arisan para ibu-ibu di kampung Klakah Rejo ini, pokonya dia tidak kembali ke pekerjaannya yang dulu sebagai PSK atau purel. Kalau berbicara adil saat masih ada istri saya yang pertama saya adil untuk istri pertama dan istri kedua untuk hal nafkah lahir maupun nafkah batin masih tetap saya lakukan. Tapi 
Mega Dwi Aprilia: Motif Poligami...

sekarang kan istri saya yang pertama sudah tidak ada, jadi adil saya hanya untuk istri kedua saya." 32

b. Istri (wanita pekerja seks komersial)

"Saya ceritakan sedikit ya mbak, dulu itu saya bisa kesini kenal dengan kerjaan begini diajak orang, orang itu bilang kalau mau diajak kerja menjadi PSK atau purel di daerah Moroseneng, dulunya saya tidak langsung menjadi PSK, tetapi saya dulu masih menjadi purel yang hanya menemani laki-laki hidung belang untuk minum (beralkohol) sama karaokean saja. Sampai saya bertemu sama suami saya ini status saya sudah pernah menikah dulunya dan mempunyai anak 2 laki-laki semuanya dan sudah berumah tangga anak-anak saya. Akhirnya ketemu dia pas di warung belakang (warung Moroseneng), awalnya hanya sekedar kenalan-kenalan saja. Pada akhirnya saya diajak ke rumah istri pertama suami saya dan diperkenalkan ke keluargnya, dari sana saya mengetahui kalau suami saya ternyata sudah mempunyai istri dan anak, hanya saja istri pertama suami saya sedang sakit parah. Kemudian saya disuruh oleh istri pertama suami saya untuk mau diajak menikah oleh suaminya. Mendengar permintaan itu saya memutuskan untuk mau dijadikan istri kedua oleh suaminya, karena saya perempuan yang pekerjaannya hanya sebagai PSK atau purel juga ingin dilindungi oleh sosok lakilaki agar saya tidak mendapat hinaan dari tetangga sekitar. Setelah hidup dipoligami suami saya masih sering $\mathrm{k}$ erumah saya terkadang juga ke rumah istrinya yang pertama, tapi sekarang istri yang pertama sudah meninggal dunia, anak-anak dari istri yang pertama juga sudah berumah tangga semua jadi sekarang suami saya pulangnya hanya ke rumah saya. Kalau ditanya keinginan untuk dinikah secara sah wanita mana yang tidak mau dinikahi secara sah mbak, semua itu keinginan para wanita tapi nanti lah mbak soalnya anak dari istri yang pertama ada yang masih tidak setuju kalau ayahnya menikah secara sah

32Sn, Wawancara Terbuka, Surabaya, 10 Desember 2016. 
dengan saya. Sudah adil untuk masalah keadilan, untuk nafkah lahir batin juga baik-baik saja." 33

3. Subjek ketiga dari pasangan suami istri berinisial Wn dengan Rh

Dalam melakukan penelitian dengan subjek ketiga ini metode wawancara dengan narasumber sangatlah berbeda dengan subjek pertama dan kedua yang menggunakan metode wawancara secara terbuka dengan melakukan tatap muka dan memberikan pertanyaan-pertanyaan langsung tentang poligami dengan narasumber. Di penelitian untuk subjek ketiga ini digunakan metode wawancara tertutup, yaitu tidak diketahuinya oleh narasumber bahwasanya peneliti ingin mengetahui seputar hidupnya yang melakukan poligami. Hal ini karena kehidupan narasumber ketiga ini sangat sulit untuk diketahui oleh orang lain. Adapun pada akhirnya dalam subjek ketiga ini peneliti hanya bisa mengetahui dari sisi istri (wanita pekerja seks komersial) saja, karena suami jarang sekali pulang. Akan tetapi, meskipun dari sedikit jawaban istri telah dapat diketahui motif suami untuk mempoligami dirinya. Berikut pernyataan istri:

"Menurut saya wanita mandiri itu bisa bertahan dari kejamnya kehidupan tanpa menggantungkan nasib ke orang lain, seperti saya begini kerja ya kerja sendiri, menghidupi anak ya sendiri, menghidupi keluarga di desa juga sendiri, menghidupi kebutuhan saya juga sendiri, sampai saya perjuangkan bekerja menjadi PSK atau purel di Moroseneng, saya juga mempunyai anak, dulunya saya pernah menikah tapi suami saya yang dulu tidak bertanggung jawab sama sekali, saya ditinggal dengan wanita lain di saat anak saya masih bayi, sakit hati saya mbak!. Saat itu saya pusing bingung saya diajak teman saya menjadi PSK atau purel di Moroseneng. Gimana ya mbak saya juga punya keinginan kerja yang benar tapi sulitnya mendapatkan pekerjaan karena hanya lulusan SD (Sekolah Dasar) dari desa juga apa yang buat menyambung hidup kalau saya tidak bekerja. Mau tidak mau saya harus menjadi

33Si, W awancara Terbuka, Surabaya, 10 Desember 2016. 
Mega Dwi Aprilia: Motif Poligami...

wanita yang mandiri di sini. Kadang saya juga mempunyai keinginan berumah tangga yang tentram seperti rumah tangga orang-orang pada umumnya. Sampai saya mau dijadikan istri kedua karena saya juga ingin mempunyai keluarga. Rumah tangga yang baik itu rumah tangga yang suaminya bisa bertanggung jawab tidak seperti suami saya dulu tidak punya hati sama sekali. Saya sekarang ini menjadi istri kedua mbak tapi suami saya jarang kesini, saya juga bisa mengerti dia juga sudah mempuyai istri sebelum saya, saya hanya mengingingkan dia bisa bertanggung jawab dan bisa melindungi saya, karena wanita seperti saya ini banyak sekali omongan-omongan miring bahkan jelek dari orang dan tetangga-tetangga sekitar, tidak apa-apa meskipun suami saya jarang pulang kesini asal dia bisa berlaku adil dalam hal nafkah, dulu suami saya ini menjadikan saya istri keduanya bilangnya hanya menaruh perasaan suka saja terhadap saya, laki-laki kalau melihat wanita apalagi wanita itu cantik kan cepat untuk jatuh cintanya, kemudian saya menceritakan kehidupan saya dulu kalau sempat ditinggal oleh suami dia langsung mengajak saya menikah dengan syarat jadi istri kedua. Tidak apa-apa lah mbak dipoligami asalkan saya ada yang melindungi, kalau dia tidak bertanggung jawab saya kan kembali lagi menjadi PSK atau purel lagi mbak, tetapi selama 3 tahun ini dia masih baik kepada saya." 34

\section{Motif Poligami dengan Wanita Pekerja Seks Komersial Eks. Lokalisasi Moroseneng di Daerah Benowo Kota Surabaya Perspektif Hukum Islam}

Dalam ketiga kasus yang telah diteliti dapat dianalisis motif poligami dengan wanita pekerja seks komersial eks. Lokalisasi Moroseneng, yaitu:

1. Pada subjek pertama sudah dipaparkan oleh suami yang berinisial Sy terkait motif melakukan poligami dengan wanita pekerja seks komersial dengan mengatakan: "Kalau ditanyai motif kenapa melakukan poligami dengan wanita PSK tidak ada melainkan

34Rh, Wawancara Tertutup, Surabaya, 11 Desember 2016. 
nafsu. Kemudian tak nikahi secara siri. Istri saya tidak mengetahui kalau saya menikah lagi, kalaupun saya mau pulang kesini saya bilang kerja ke istri saya." 35

2. Pada subjek kedua sudah dipaparkan oleh suami yang berinisial Sn terkait motif melakukan poligami dengan wanita pekerja seks komersial dengan mengatakan "Kalau ditanya motifnya ya menerima keinginan dari istri saya yang pertama untuk saya menikah lagi biar saya bisa menolong istri saya yang kedua untuk jadi orang baik-baik dan tidak kembali ke pekerjaannya menjadi PSK atau purel, awalnya juga saya tidak pernah melakukan halhal buruk sama dia, hanya saja kenal langsung saya ajak menikah, niat saya juga baik niat lillahita'ala." 36

3. Pada subjek ketiga sudah dipaparkan oleh istri dari suami yang berinisial Wn yaitu Rh terkait motif melakukan poligami dengan wanita pekerja seks komersial dengan mengatakan "Dulu suami saya ini menjadikan saya istri keduanya bilangnya hanya menaruh perasaan suka saja terhadap saya, laki-laki kalau melihat wanita apalagi wanita itu cantik kan cepat untuk jatuh cintanya, kemudian saya menceritakan kehidupan saya dulu kalau sempat ditinggal oleh suami dia langsung mengajak saya menikah dengan syarat jadi istri kedua." 37

Berdasarkan dari hasil wawancara dengan para pelaku poligami di atas terdapat beberapa unsur motif poligami suami yang diketahui, yaitu karena nafsu seksual yang tinggi dan rasa ingin meningkatkan derajat para wanita pekerja seks komersial atau purel menjadi lebih baik, sedangkan motif poligami wanita pekerja seks komersial (istri) yaitu mempunyai keinginan untuk menjadi wanita yang baik-baik dan merasa ingin dilindungi sebagaimana wanita pada umumnya.

Jika dibandingkan motif poligami Nabi Muhammad Saw. dengan motif poligami yang ada di zaman sekarang, seperti halnya motif poligami dengan wanita pekerja seks di eks. Lokalisasi Moroseneng sebenarnya tidak jauh berbeda, yaitu keduanya samasama bermotif menolong serta mengangkat derajat wanita untuk

35Sy, Wawancara Terbuka, Surabaya, 09 Desember 2016.

${ }_{36} \mathrm{Sn}$, Wawancara Terbuka, Surabaya, 10 Desember 2016.

37Rh, Wawancara Tertutup, Surabaya, 11 Desember 2016. 
lebih mulia. Hanya saja di zaman sekarang motif poligami yang dilakukan oleh Nabi Muhammad saw. tidak diterapkan semuanya, seperti halnya pada kasus motif poligami yang ada di eks. Lokalisasi Moroseneng, yaitu motif menikahi wanita pekerja seks komersial adalah seksual tetapi bukan menjadi tujuan utama. Adapun yang menjadi tujuan utamanya adalah menolong dan mengangkat derajat para wanita pekerja seks komersial untuk menjadi wanita baik-baik.

Jika berpoligami hanya karena seksual yang tinggi maka hukumnya tidak sunnah melainkan bisa jadi haram, karena mengatasnamakan agama untuk memuaskan syahwat dan jika dalam poligaminya ditujukan untuk menyakiti istrinya karena hanya menyalurkan hawa nafsu serta tidak berlaku adil sebagimana menjadi syarat yang utama dalam Islam untuk berpoligami juga haram hukumnya sebagaimana pendapat al-Maraghi yang menyatakan bahwa motif Nabi Muhammad saw. berpoligami menurutnya ditujukan untuk syiar Islam, sebab jika tujuannya untuk pemuasan nafsu seksual, tentu Nabi akan memilih perempuan-perempuan cantik dan yang masih gadis, padahal sejarah membuktikan bahwa yang dinikahi Nabi semuanya janda kecuali 'Aisyah.38

Nabi Muhammad saw. sendiri telah menganjurkan poligami bagi mereka yang mampu menafkahi, mendidik, membimbing ke jalan yang benar, dan berbuat adil. Oleh karena itu, jika dalam hal ini motif poligami adalah menolong untuk memimpin wanita dan membimbing mereka dalam kebaikan dan menjaga mereka dari keburukan, memberi mereka nafkah yang halal, serta bisa berbuat adil kepada para istri-istrinya, maka hukum poligami di sini adalah sunnah dan juga diperbolehkan.

\section{Penutup}

Motif poligami dengan wanita pekerja seks komersial atau purel eks. Lokalisasi Moroseneng di daerah Benowo kota Surabaya adalah motif seksual dan motif menolong, yang mana motif seksual bukan menjadi tujuan utama, tetapi yang menjadi keutamaannya menolong serta mengangkat derajat para wanita pekerja seks komersial untuk menjadi wanita baik-baik. Motif poligami tersebut sebenarnya tidak jauh berbeda dengan motif poligami Nabi

38 Ahmad Musthafa Al-Maraghi, Tafsir al-Maraghi, 173. 
Muhammad saw., yaitu motif menolong serta mengangkat derajat wanita untuk lebih mulia, hanya saja tidak sepenuhnya diterapkan karena tetap adanya motif seksual meskipun tidak menjadi motif utamanya.

Nabi Muhammad Saw. sendiri telah menganjurkan poligami bagi mereka yang mampu menafkahi, mendidik, membimbing ke jalan yang benar, dan berbuat adil. Oleh karena itu, jika dalam hal ini motif poligami adalah menolong untuk memimpin wanita dan membimbing mereka dalam kebaikan dan menjaga mereka dari keburukan, memberi mereka nafkah yang halal, serta bisa berbuat adil kepada para istri-istrinya, maka hukum poligami di sini adalah sunnah dan juga diperbolehkan.

Sesungguhnya poligami itu lebih baik daripada berselingkuh atau berzina, poligami itu halal, sementara berzina itu haram. Dalam Islam seorang laki-laki justru lebih baik dan mulia jika ia menikah lagi (berpoligami) daripada ia berzina atau melacur. Oleh karena itu, untuk para laki-laki yang berpoligami niatlah karena engkau menolong atau ingin mengangkat derajat wanita dan membimbing mereka ke dalam kebaikan seperti apa yang pernah dilakukan Rasulullah saw. dan berbuatlah adil kepada para istri-istrimu supaya engkau terhindar dari dosa.

\section{Daftar Pustaka}

Asghar Ali. Pembebasan Perempuan. Yogyakarta: Lkis, 2003.

Muhammad Daud Ali. Hukum Islam dan Peradilan Agama. Jakarta: PT Raja Grafindo Persada,1997.

Aishah Bintush-Shati'. Istri-istri Nabi, Fenomena Poligami di Mata Seorang Tokoh Wanita. Bandung: Pustaka Hidayah, 2001.

Mu'ammal Hamidy. et. al. Terjemahan Nailul Authar, jilid 5. Surabaya: Pt Bina Ilmu, 1993.

Yahya Harahap. Hukum Perkawinan Nasional. Medan: Zahir Tranding Co Medan, 1975.

Imam Taqiyuddin Abi Bakr al-Husaini. Kifayah Al-Akhyar, jilid II. Bandung: PT. Al-Ma'arif, t.t.

Ahmad Musthafa al-Maraghi. Tafsir al-Maraghi, jilid IV. Mesir: Mushthafa al-Bab al-Halabi, 1969. 
Mega Dwi Aprilia: Motif Poligami...

Siti Musdah Mulia. Islam Menggugat Poligami. Jakarta: PT Gramedia Pustaka Utama, 2007.

Agus Mustofa. Benarkah al-Qur'an Menyuruh Berpoligami karena Alasan Syahwat?. Surabaya: Padma Press, 2008. -, Poligami Yunk!?. Surabaya: PADMA Press, 2010.

Khairuddin Nasution. Riba \& Poligami: Sebuah Studi atas Pemikiran Muhammad Abduh, cet. I. Yogyakarta: Pustaka Pelajar, 1996. -,Riba dan Poligami: Sebuah Studi atas Pemikiran Muh. Abduh. Yogyakarta: Aca Nemia, t.t.

Syekh Muhammad Yusuf Qardhawi. Halal \& Haram Dalam Islam, terj. Hamidy Muammal. Surabaya: PT Bina Ilmu Surabaya, 2010.

Al-Qurthubi. Al-Jami' li al-Ahkam al-Qur'an, jilid V. Kairo: Dar alKitab al-'Arabiyyah, 1967.

Sumiati. Hukum Perkawinan Islam dan Undang-Undang Perkawinan No.1 Tabun 1974 Yogyakarta: Liberti, 1985.

Al-Syaukani. Fath al-Qadir: al-Jami' Bain Fann al-Riwayah wa al-Dirayah min 'Ilm al-Tafsir, jilid I. Beirut: Dar al-Fikr, 1973.

Ibnu Jarir al-Thabari. Jami' al-Bayan fi Tafsir al-Qur'an, jilid IV. Beirut: Dar al-Fikr, 1978.

Sabiq, Sayid. Fikih Sunnah, terj. Moh Tholib, juz VI. Bandung: PT. Al-ma'arif,1990.

Departemen Agama. Al-Qur'an dan Terjemahannya. Jakarta: Pustaka Amani, 2002.

Departemen P dan K. Kamus Besar Bahasa Indonesia. Jakarta: Balai Pustaka, 1989.

Riyanto. Wawancara Terbuka. Surabaya, 06 Desember 2016.

Si. Wawancara Terbuka. Surabaya, 10 Desember 2016.

Sn. Wawancara Terbuka. Surabaya, 10 Desember 2016.

Sr. Wawancara Terbuka. Surabaya, 09 Desember 2016.

Sunarto. Wawancara Terbuka. Surabaya, 06 Desember 2016.

Sy. Wawancara Terbuka. Surabaya, 09 Desember 2016.

Rh. Wawancara Tertutup. Surabaya, 11 Desember 2016. 